Kong. Res. J. 1(2): 121-125, 2014

Kongunadu Arts and Science College, Coimbatore

\title{
INVASIVE ALIEN WEEDS AND THEIR ETHNO-BOTANICAL IMPORTANCE OF VIJAYAMANGALAM VILLAGE, ERODE DISTRICT
}

\author{
Uma, G., ${ }^{*}$ S. Jagathes Kumar and V. Balasubramaniam \\ Department of Botany, Kongunadu Arts and Science College, Coimbatore. \\ *E.mail: umaphd430@gmail.com
}

\section{ABSTRACT}

The present study deals with comprehensive list of Invasive alien plants of Vijayamangalam village, Perundurai taluk, Erode district with background information on family, habit and nativity. A total of 50 invasive alien species under 40 genera, belonging to 18 families have been recorded. While in life form analysis, the herbs (40 species) are dominant, followed by shrubs (6 species), Climber ( 2 species), Trees (2 species).

Key words: Invasive alien species, Vijayamangalam, family, nativity.

\section{INTRODUCTION}

Alien species are non-native or exotic organisms that occur outside their natural adapted ranges and dispersal potential. Many alien species support our farming and forestry systems in a big way. However, some of the alien species become invasive when they are introduced deliberately or unintentionally outside their natural habitats into new areas where they express the capability to establish, invade and out compete native species. International Union for Conservation of Nature and Natural Resources (IUCN) defines Alien Invasive Species as an alien species which becomes established in natural or seminatural ecosystems or habitat, an agent of change, and threatens native biological diversity. These invasive are widely distributed in all kinds of ecosystems throughout the world, and include all categories of living organisms. Nevertheless, plants, mammals and insects comprise the most common types of invasive alien species in terrestrial environments (Raghubanshi et al., 2005). Exotic weeds cause loss of biodiversity including species extinctions and changes in hydrology and ecosystem function. Some alien or exotic weeds could affect ecosystem properties by bringing nutrient to the surface from deep in the soil, thus serving as "pumps" which keep high levels of essential nutrients in circulation.

Many agriculturists have recognized that weeds despite their nuisance value do at times serve some useful purpose. Weeds often provide a protective cover against surface washing and run off. Moreover weeds are frequently used in the form of mulch around cultivated plants. Some antibiotics, as well as bio pesticides have been extracted from weeds. Apart from this many weeds are used as high poison, green manures and pollution indicators.

Weeds are comprised of the more aggressive, troublesome and undesirable elements of the World's vegetation. More than $80 \%$ of the developing world continues to rely on traditional medicines predominantly plants, for primary healthcare. The global demand for herbal medicine is not only large, but also growing. The market for Ayurvedic medicine is estimated to be expanding at $20 \%$ annually in India (Jeeva et al., 2006).

\section{METHODOLOGY}

\subsection{Study area}

The study area Vijayamangalam village located in Perundurai taluk under Erode district. The major occupation of the peoples is agriculture and Hand loom weaving. Erode experiences hot and dry weather throughout the year. The temperature ranges from a maximum of $96^{\circ} \mathrm{F}\left(36^{\circ} \mathrm{C}\right)$ to a minimum of $80^{\circ} \mathrm{F}\left(27^{\circ} \mathrm{C}\right)$

Field trips were made during the study period 2012- 2013. The entire area was covered at different seasons. Specimens collected from the study area were identified carefully using the Flora of the Presidency of Madras by J.S. Gamble \& C.E.C. Fischer (1915- 1935), Flora of TamilNadu Carnatic by K.M.Mathew, (1983). Identity of the plants was confirmed after critical studies with reference to authentic materials available in the Herbarium of The Botanical Survey of India, Southern circle, Coimbatore (MH) and Herbarium of Kongunadu Arts and Science College, (KASCH). 


\section{RESULTS}

The weeds, which are best known and most highly regarded in traditional medicine, are enumerated with botanical name, local name (in Tamil), family, medicinal uses and nativity. 50 medicinal weed species belonging to 18 families and 40 genera have been recorded (Table-1). Amaranthaceae was the dominant family with 12 species, followed by Asteraceae (7 species), Malvaceae, Caesalpinaceae, Asclepiadaceae, Convolvulaceae and Nyctanginaceae (3 species each). 5 families were represented by 2 species and 6 families represented by single species. Most of the medicinal plants are common are growing in wild condition as weeds.

\section{DISCUSSION}

Alien species are non-native or exotic organisms that occur outside their natural adapted ranges and dispersal potential (McGeoch et al., 2010). Many alien species support our farming and forestry systems in a big way. However, some of the alien species become invasive when they are introduced deliberately or unintentionally outside their natural habitats into new areas where they express the capability to establish, invade and outcompete native species. International Union for Conservation of Nature and Natural Resources (IUCN) defines Alien Invasive Species as an alien species which becomes established in natural or semi-natural ecosystems or habitat, an agent of change, and threatens native biological diversity. These invasive are widely distributed in all kinds of ecosystems throughout the world, and include all categories of living organisms. Nevertheless, plants, mammals and insects comprise the most common types of invasive alien species in terrestrial environments (Raghubanshi et al., 2005).

\section{REFERENCES}

Gamble.J.S and C.E.C.Fisher, (1957). Flora of the Presidency of Madras, (repr. ed) 1-3 Calcutta.

Jeeva, S., S.Kiruba, B.P. Mishra, N. Venugopal, S.S.M. Dhas, G.S. Regini, C. Kingston, A. Kavitha, S. Sukumaran, A.D.S. Raj and R.C. Laloo. (2006). Weeds of Kanyakumari district and their value in rural life, Indian journal of traditional Knowledge, 5(4), Pp. 501-509.

Mathew, K.M. (1983). The Flora of Tamilnadu Carnatic, 3(1-3), Rapinet herbarium, Tiruchirapalli.

McGeoch, M.A., S.H.M. Butchart, D. Spear, E. Marais, E.J. Kleynhans, A. Symes, J. Chanson and M. Hoffmann, ( 2010). "Global Indicators of Biological Invasion: Species Num-bers, Biodiversity Impact and Policy Responses," Diver-sity and Distributions, 16, 1: pp. 95-108.

Raghubanshi, A.S., L.C. Rai, J.P. Gaur and J.S. Singh, (2005). Invasive alien species and biodiversity in India, Current Science, 539-540.

\section{Invasive Alien plants in Vijayamangalam, Erode District}

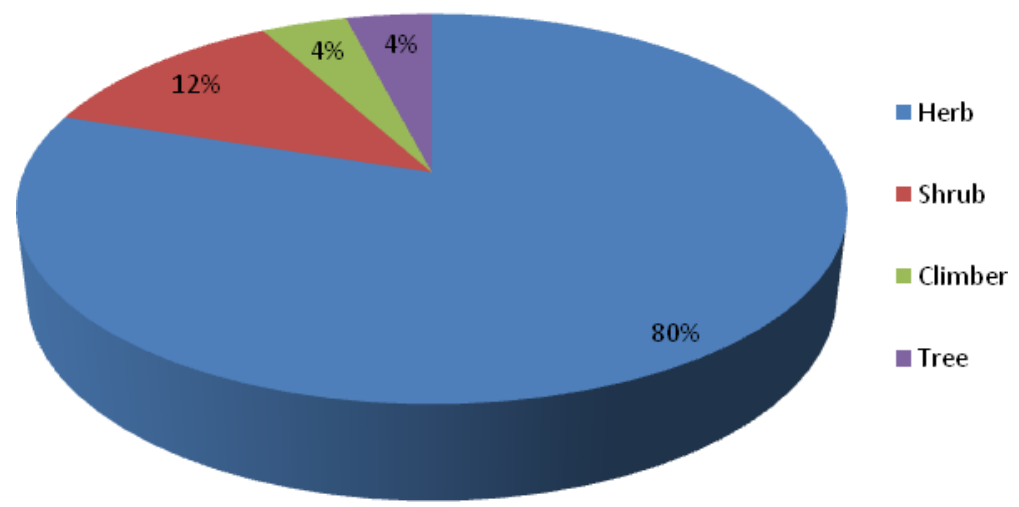


Table 1. Ethnomedicinal uses of Invasive Alien plants in Vijayamangalam, Erode District.

\begin{tabular}{|c|c|c|c|c|c|}
\hline S. No & Botanical name & Family & Habit & Medicinal uses & Native \\
\hline 1. & Argemone Mexicana & Papaveraceae & Herb & Latex of the plant is applied topically on the site of boils & $\begin{array}{l}\text { Trop. Central \& } \\
\text { South America }\end{array}$ \\
\hline 2. & Cleome viscosa & Capparidaceae & Herb & $\begin{array}{l}\text { Plant is used in various disorders such as diarrhoea, fever, } \\
\text { inflammation, liver diseases, bronchitis, skin diseases, and malarial } \\
\text { fever. }\end{array}$ & Trop.America \\
\hline 3. & $\begin{array}{l}\text { Gynandropsis } \\
\text { pentaphylla }\end{array}$ & Capparidaceae & Herb & $\begin{array}{l}\text { The decoction of leaves is used in chronic fever. Leaves areapplied to } \\
\text { prevent the pus formation of boils. The juice of the leaves is poured into } \\
\text { ears for earache and otalgia. The seeds paste is applied externally to } \\
\text { expel the vermin from the hairs. }\end{array}$ & Trop.America \\
\hline 4. & Abutilon indicum & Malvaceae & Shrub & $\begin{array}{l}\text { Demulcent, aphrodisiaclaxative, diuretic, sedative, astringent, } \\
\text { expectorant, tonic, anti inflammatory,anthelmintic, and analgesic. }\end{array}$ & Trop.America \\
\hline 5. & Sida acuta & Malvaceae & Herb & $\begin{array}{l}\text { Flowers paste is given in boils and burns. Root paste is applied in snake } \\
\text { bite. Leaf is given in gastric disorder and stomach pain }\end{array}$ & Central America \\
\hline 6. & $\begin{array}{l}\text { Malvastrum } \\
\text { coromandelianum }\end{array}$ & Malvaceae & Herb & Leaves used to clean wounds; also used for dysentery. & America \\
\hline 7. & Tribulus terrestris & Zygophyllaceae & Herb & Root is used as Urinary stones, infections. & Trop.America \\
\hline 8. & Abrus precatories & Fabaceae & climber & Skin related problems, Scratches from pet animals, Abdominal Pain & Indonesia \\
\hline 9. & Crotaleria pallida & Fabaceae & Shrub & $\begin{array}{l}\text { To treat urinary problems. A poultice made from the roots is applied to } \\
\text { painful swelling of joints, and an extract of the leaves is taken as a } \\
\text { vermifuge. }\end{array}$ & Africa \\
\hline 10. & Cassia tora & Caesalpinaceae & Herb & $\begin{array}{l}\text { Leaf is useful in night blindness and leaf paste is used in cuts, boils, } \\
\text { burns and as antiseptic treatment. Seed is given in stomach pain. Root is } \\
\text { given in fever and abnormal child growth. }\end{array}$ & $\begin{array}{l}\text { Trop. South } \\
\text { America }\end{array}$ \\
\hline 11. & Cassia occidentalis & Caesalpinaceae & Herb & Leaves used to cure Skin diseases, Antiperiodic. & $\begin{array}{l}\text { Trop. South } \\
\text { America }\end{array}$ \\
\hline 12. & Cassia hirsuta & Caesalpinaceae & Herb & $\begin{array}{l}\text { The root is pasted with cumin and taken internally to treat stomach } \\
\text { burning after a meal. }\end{array}$ & Trop. America \\
\hline 13. & Acacia nilotica & Mimosaceae & Tree & $\begin{array}{l}\text { Gargle for toothache, gum disorders, toothbrush. } \\
\text { To treat eye conditions, open wounds and dermatological ailments. }\end{array}$ & Trop. America \\
\hline 14. & Prosopis juliflora & Mimosaceae & Tree & & Trop. America \\
\hline 15. & Opuntia dillenii & Cactaceae & Herb & $\begin{array}{l}\text { Anti-diabetic, anti-inflammatory, analgesic, galactogogue, hypoglycemic, } \\
\text { antiviral and anti-oxidant. }\end{array}$ & Trop.America \\
\hline 16. & Passiflora foetida & Passifloraceae & Herb & $\begin{array}{l}\text { Decoction of fruit used for asthma and biliousness. Leaves applied to the } \\
\text { head for headaches and giddiness. }\end{array}$ & $\begin{array}{l}\text { Trop. South } \\
\text { America }\end{array}$ \\
\hline 17. & $\begin{array}{l}\text { Acanthospermum } \\
\text { hispidum }\end{array}$ & Asteraceae & Herb & $\begin{array}{l}\text { The crushed herb is used in the form of a paste to treat skin ailments } \\
\text { and the leaf juice is reportedly used to relieve fevers. }\end{array}$ & Brazil \\
\hline
\end{tabular}




\begin{tabular}{|c|c|c|c|c|c|}
\hline 18. & $\begin{array}{l}\text { Ageratum } \\
\text { conyzoides }\end{array}$ & Asteraceae & Herb & $\begin{array}{l}\text { The leaves are used in leprosy and uterine disorder, also used in killing } \\
\text { the hairs lice. Leaf paste is applied on cuts, wounds, and burns. Leaf } \\
\text { juice is useful skin disease and scabies disease. }\end{array}$ & Trop. America \\
\hline 19. & $\begin{array}{l}\text { Ageratum } \\
\text { houstonianum }\end{array}$ & Asteraceae & Herb & Plant juice is used externally to treat cuts and wounds. & Trop. America \\
\hline 20. & $\begin{array}{l}\text { Xanthium } \\
\text { strumarium }\end{array}$ & Asteraceae & Herb & $\begin{array}{l}\text { Laxative, fattening, anthelmintic, alexiteric, tonic, digestive, antipyretic, } \\
\text { and improves appetite, voice, complexion, and memory. }\end{array}$ & Trop. America \\
\hline 21. & $\begin{array}{l}\text { Parthenium } \\
\text { hysterophorus }\end{array}$ & Asteraceae & Herb & $\begin{array}{l}\text { Flowers are useful in nasal block in cold. Leaves mixed with two or } \\
\text { three pieces of garlics and made into fine paste, the paste is squeezed } \\
\text { juice put in ear to stop pus flow. }\end{array}$ & $\begin{array}{l}\text { Trop. North } \\
\text { America }\end{array}$ \\
\hline 22. & Tridax procumbens & Asteraceae & Herb & $\begin{array}{l}\text { Pasteof leaf is given in boils, cuts \& wounds. Leaf is also useful in } \\
\text { diarrhea, dysentery and leprosy }\end{array}$ & $\begin{array}{l}\text { Trop. Central } \\
\text { America }\end{array}$ \\
\hline 23. & Lagascea mollis & Asteraceae & Herb & $\begin{array}{l}\text { Leaf paste is given in cuts and wounds. Flowers are given for ear } \\
\text { complaints. }\end{array}$ & $\begin{array}{l}\text { Trop. Central } \\
\text { America }\end{array}$ \\
\hline 24. & $\begin{array}{l}\text { Catharanthus } \\
\text { pusillus }\end{array}$ & Apocynaceae & Herb & The whole plant is used to cure cancer and diabetic & Trop.America \\
\hline 25. & Daemeia extensa & Asclepiadaceae & Climber & $\begin{array}{l}\text { Leaves can be treat diarrhea among children, intestinal worms. } \\
\text { Root is used Eczema, leprosy, elephantiasis, asthma, cough and }\end{array}$ & Trop. America \\
\hline 26. & Calotropis procera & Asclepiadaceae & Shrub & $\begin{array}{l}\text { rheumatism, To treat common diseases such as fever, rheumatism, } \\
\text { indigestion, cold, eczema and diarrhea. }\end{array}$ & Trop. Africa \\
\hline 27. & $\begin{array}{l}\text { Calotropis } \\
\text { gigantean }\end{array}$ & Asclepiadaceae & Shrub & Latex - Arthritis. Roots - Uterine disorders. & Trop. Africa \\
\hline 28. & Ipomea obscura & Convolvulaceae & Herb & $\begin{array}{l}\text { The fresh plant extract is mixed with gingely oil and is used to cure cold, } \\
\text { asthma and dry cough. }\end{array}$ & Trop. Africa \\
\hline 29. & Merremia aegyptia & Convolvulaceae & Herb & $\begin{array}{l}\text { Leaves are ground and } 30 \mathrm{ml} \text { of the extracted juice is taken once a day } \\
\text { till cure jaundice. }\end{array}$ & Trop. America \\
\hline 30. & Cuscuta chinensis & Convolvulaceae & Herb & $\begin{array}{l}\text { The paste of plant is applied on chronic ulcer, wounds. Poultice is } \\
\text { applied on painful inflammations. }\end{array}$ & Mediterranean \\
\hline 31. & Datura metal & Solanaceae & Shrub & $\begin{array}{l}\text { The fresh leaves are boiled with gingelly oil and applied topically on } \\
\text { joints to cure swellings }\end{array}$ & America \\
\hline 32. & Martynia annua & Pedaliaceae & Herb & Leaves used antiepileptic and antiseptic, itching and skin affections & T.America \\
\hline 33. & Pedalium murex & Pedaliaceae & Herb & $\begin{array}{l}\text { puerperal diseases, digestive tonics, ulcers, fevers, wounds, other } \\
\text { ailments and general debility }\end{array}$ & Trop. America \\
\hline
\end{tabular}




\begin{tabular}{|c|c|c|c|c|c|}
\hline 34. & Lantana camera & Verbenaceae & Shrub & $\begin{array}{l}\text { Leaves are used to treat cuts, rheumatisms, ulcers, catarrhal infection, } \\
\text { tetanus, rheumatism, malaria, cancer, chicken pox. }\end{array}$ & Trop. America \\
\hline 35. & Lippia nodiflora & Verbenaceae & Herb & $\begin{array}{l}\text { Whole plant is used for hepatitis and against abscess. Leaves are used } \\
\text { against anti dote for snake sting. }\end{array}$ & \\
\hline 36. & Boerhaavia diffusa & Nyctanginaceae & Herb & $\begin{array}{l}\text { Whole plant is used Jaundice, eye complaint, child birth andliver } \\
\text { complaint }\end{array}$ & Trop. America \\
\hline 37. & $\begin{array}{l}\text { Boerhaavia } \\
\text { verticillata }\end{array}$ & Nyctanginaceae & Herb & Root pieces are kept in the mouse to cure mouth ulcers. & Trop. America \\
\hline 38. & Mirabilis jalapa & Nyctanginaceae & Herb & $\begin{array}{l}\text { The leaves are used to reduce inflammation. A decoction of them } \\
\text { (mashing and boiling) is used to treat abscesses. Leaf juice may be used } \\
\text { to treat wounds. }\end{array}$ & Peru \\
\hline 39. & Aerva lanata & Amaranthaceae & Herb & $\begin{array}{l}\text { treatment of diabetes mellitus, urinary calculi, hematesis, bronchitis, } \\
\text { nasal bleeding, cough, scorpion stings, fractures, spermatorrhea, to clear } \\
\text { uterus after delivery and also to prevent lactation }\end{array}$ & Trop. America \\
\hline 40. & Aerva tomentosa & Amaranthaceae & Herb & $\begin{array}{l}\text { The herb is used for diuretic and demulcent. Its decoction is used } \\
\text { remove swellings. }\end{array}$ & Trop. America \\
\hline 41. & $\begin{array}{l}\text { Alternanthera } \\
\text { paronychioides }\end{array}$ & Amaranthaceae & Herb & Leaves and stem used for Urine complaints. & Trop.America \\
\hline 42. & $\begin{array}{l}\text { Alternanthera } \\
\text { pungens }\end{array}$ & Amaranthaceae & Herb & Leaf decoction used for Diuretic, decoction in gonorrhea. & Trop. America \\
\hline 43. & $\begin{array}{l}\text { Alternanthera } \\
\text { philoxeroides }\end{array}$ & Amaranthaceae & Herb & Whole plant used for Allelopathic. & Trop. America \\
\hline 44. & Amaranthus viridis & Amaranthaceae & Herb & $\begin{array}{l}\text { The paste of the root is applied on scorpion sting. It is used as a potherb } \\
\text { for the alleviation of heat from the body. It is also supposed to be } \\
\text { effective in kidney and gall bladder stones when used as potherb. }\end{array}$ & Trop. America \\
\hline 45. & Digera muricata & Amaranthaceae & Herb & Plant is used as potherb and reported as a laxative agent. & SW Asia \\
\hline 46. & $\begin{array}{l}\text { Alternanthera } \\
\text { tenella }\end{array}$ & Amaranthaceae & Herb & Ear problems & Trop. America \\
\hline 47. & Celosia argentea & Amaranthaceae & Herb & $\begin{array}{l}\text { Seeds traditionally used for treatment of jaundice, gonorrhea, wounds } \\
\text { and fever. }\end{array}$ & Trop. Africa \\
\hline 48. & $\begin{array}{l}\text { Amaranthus } \\
\text { spinosus }\end{array}$ & Amaranthaceae & Herb & $\begin{array}{l}\text { Leaves are also used for gastroenteritis, gall bladder inflammation, } \\
\text { absesses, arthritis and for the treatment of snakebites. }\end{array}$ & Trop. America \\
\hline 49 & Achyranthes aspera & Amaranthaceae & Herb & $\begin{array}{l}\text { astnma, bleeding, in racilltating delivery, bolls, bronchitis, cold, cough, } \\
\text { colic, debility, dropsy, dog bite, dysentery, ear complications, headache, } \\
\text { leucoderma, pneumonia, renal complications, scorpion bite, snake bite } \\
\text { and skin diseases }\end{array}$ & Trop. America \\
\hline 50. & $\begin{array}{l}\text { Achyranthes } \\
\text { bidentata }\end{array}$ & Amaranthaceae & Herb & $\begin{array}{l}\text { Stimulate menstruation, ease menstrual pain,relieve lower back pain, } \\
\text { canker sores, toothache, bleeding gums, nosebleeds. }\end{array}$ & Trop. America \\
\hline
\end{tabular}

